\title{
EVALUASI PEMANFAATAN PELABUHAN KAMAL UNTUK WISATA BAHARI PASCA PEMBANGUNAN JEMBATAN SURAMADU MENGGUNAKAN PEMODELAN RAPFISH
}

\section{Evaluation of The Use of Kamal Port For Bahari Tourism Suramadu Bridge Using Rapfish Modeling}

\author{
*Firman Farid Muhsoni, Muhammad Zainuri, dan Indah Wahyuni Abida \\ Universitas Trunojoyo Madura \\ JI. Raya Telang, Perumahan Telang Inda, Kabupaten Bangkalan, Jawa Timur 69162, Indonesia \\ Diterima tanggal: 13 Oktober 2019; Diterima setelah perbaikan: 20 Mei 2021; \\ Disetujui terbit: 25 Juni 2021
}

\begin{abstract}
ABSTRAK
Pasca pembangunan Jembatan Suramadu, Pelabuhan Kamal mengalami penurunan aktivitas secara drastis. Kondisi ini menyebabkan penurunan pendapatan masyarakat sebesar $98 \%$. Pemerintah Kabupaten Bangkalan merencanakan untuk mengembangkan kawasan Pelabuhan Kamal sebagai alternatif penyeberangan dan wisata baharí. Tujuan penelitian ini adalah menganalisis keberlanjutan wisata bahari yang direncanakan tersebut, ditinjau dari dimensi ekologis, sosial, ekonomi, potensi sumber daya, hukum dan kelembagaan. Metode yang digunakan adalah Rapid Appraissal for Fisheries (RAPFISH), yang didasarkan pada teknik ordinasi menggunakan Multi-Dimensional Scaling (MDS). Data diambil dengan kuesioner yang digunakan untuk melakukan wawancara terhadap 43 responden yang melakukan aktivitas di Pelabuhan, yaitu wiraswata/pedagang 28 orang, pegawai pemerintah 4 orang dan penduduk 11 orang. Hasil analsis menunjukkan bahwa indeks keberlanjutan untuk dimensi ekologi adalah 43,52, dimensi sumber daya 31,84, dimensi ekonomi 35,78, dan dimensi sosial 31,84 dan dikategorikan sebagai 'kurang berkelanjutan'. Sementara itu, dimensi hukum dan kelembagaan mempunyai nilai 10,33 sehingga dikategorikan sebagai 'tidak berkelanjutan'. Hasil ini menunjukkan bahwa semua dimensi memerlukan intervensi sehingga rencana pembangunan wisata bahari di Suramadu oleh Pemerintah Kabupaten Bangkalan dapat berlanjut. Dari hasil analisis leverage, diperoleh hasil bahwa intervensi direkomendasikan untuk diprioritaskan pada atribut ekologi, potensi sumber daya, ekonomi, sosial, hukum dan kelembagaan.
\end{abstract}

Kata Kunci: Kamal; Rapfish; MDS; wisata bahari; Suramadu

\begin{abstract}
After the construction of Suramadu Bridge, Kamal Port experienced a drastic decline in its activity. This condition caused a decrease in people's income by up to 98\%. The Bangkalan Regency Government has planned to develop the Kamal Port area as an alternative crossing and marine tourism. The study aimed to analyze the sustainability index of marine tourism plan at the Kamal Port based on ecological, social, economic, potential resource, legal, and institutional. The method used was Rapid Appraisal for Fisheries (RAPFISH) based on ordination technique using Multi-Dimensional Scaling (MDS). Data were collected thorugh questionnaired interviews with 43 relevant respondents at the port, namely 28 entrepreneurs/traders, 4 government officials, and 11 residents. Result of the analysis showed that the sustainability index of ecological dimension was 43.52, resources 31.84, economy 35.78, social 31.84, all of which fell into the less sustainable category. Meanwhile, the legal and institutional dimensions have a value of 10.33, all of which were categorized as 'unsustainable'. These results suggest further intervention on all dimension for the continuity of the marine tourism plan in Suramadu. Based on the leverage analysis, it is recommended to prioritize intervention on ecological, resource potential, economic, social, legal, and institutional attributes.
\end{abstract}

Keywords: Kamal; Rapfish; MDS; marine tourism; Suramadu 


\section{PENDAHULUAN}

Di dalam Rumusan Strategi dan Skenario Pembiayaan Penyeberangan Ujung Kamal (2011) disebutkan bahwa sebelum adanya Jembatan Suramadu, Pelabuhan Kamal merupakan salah satu gerbang utama menuju Pulau Madura. Pelabuhan tersebut menciptakan berbagai kegiatan sosial ekonomi masyarakat empat kabupaten di Pulau Madura, yang kemudian sangat bergantung pada kegiatan penyeberangan di pelabuhan tersebut (Widjajanto, R., Kumalawati, N., \& Zefri, 2017). Perkembangan sosial ekonomi tersebut sangat bervariasi. Pada bidang ekonomi misalnya adalah berbagai kegiatan penjualan produkproduk bermerek seperti KFC, Dunkin Donat dsb., maupun penyedia produk-produk lokal termasuk toko-toko cemilan, buah, souvenir, warung nasi, restoran, pasar, dan sebagainya. Kegiatan-kegiata ekonomi tersebut juga meningkatkan pendapatan daerah, dimana Pelabuhan Kamal menyumbang penghasilan daerah melalui pajak barang yang diangkut melalui pelabuhan tersebut; sebelum adanya Jembatan Suramadu. Tahun 2008 pelabuhan tersebut secara total melayani penumpang roda 2 , roda 4 dan bagasi sebanyak 8.307.522 dan pada tahun 2009 (setelah peresmian Jembatan Suramadu) turun $27,67 \%$ menjadi 6.009.223. Dari sudut pandang sosial, kontribusi penting pelebuhan tersebut adalah dalam bentuk penyediaan lapangan pekerjaan akses urbanisasi (Jannah, 2016).

Pasca pembangunan Jembatan Suramadu, Pelabuhan Kamal mengalami penurunan aktivitas secara drastis. Jumlah kapal ferry yang beroperasi menurun dari 19 kapal tahun 2008 menjadi 3 unit kapal tahun 2010 (Andriyani, Muna, \& Nofeti, 2019). Tiga kapal yang masih beroperasi, 2 kapal milik ASDP dan 1 kapal milik swasta kerugian rata-rata Rp 15 miliar per tahun (Salman, 2018; Bisri, 2019). Sejauh ini kegiatan-kegiatan ekonomi yang baru masih sulit berkembang karena sejumah faktor. Beberapa faktor tersebut di antaranya adalah minimnya investasi, tingginya intensitas pemanfaatan lahan, penurunan aktivitas ekonomi, belum adanya kebijakan pemerintah, belum jalannya regulasi pemanfaatan ruang, buruknya pemenuhan fasilitas dan pelayanan, belum adanya kebijakan pengelolaan kawasan pelabuhan, dan partisipasi masyarakat yang terbatas (Widjajanto et al., 2017). Perurunan aktivitas lama dan belum berkembangnya kegiatan baru menyebabkan penurunan pendapatan masyarakat sebesar $98 \%$. .
Pemerintah Kabupaten Bangkalan merencanakan untuk mengarahkan Kawasan Pelabuhan Kamal menjadi alternatif penyeberangan dan wisata baharí (Widjajanto et al., 2017). Arahan revitalisasi Pelabuhan Kamal dilakukan melalui: pengembangan wisata bahari, pengembangan bangunan maupun sarana dan prasarana untuk mendukung wisata bahari, aspek institusional untuk mendukung wisata bahari (Akbarwati \& Ariastita, 2013). Ada sebagian pihak yang skeptis terhadap rencana ini karena pembangunan wisata belum tentu memberikan multiplier effect yang tinggi terhadap masyarakat (Mira, 2014). Dengan latar belakang ini, perlu dilakukan kajian yang dapat memberikan gambaran terntang prospek dari rencana pemerintah kabupaten tersebut. Dalam makalah ini, dilaporkan hasil penelitian terkait, yang ditujukan untuk menganalisis keberlanjutan daya dukung ekologis, sosial, ekonomi, potensi sumber daya, hukum dan kelembagaan di Pelabuhan Kamal sebagai wisata bahari.

\section{RAPID APPRAISSAL FOR FISHERIES (RAPFISH)}

Metode yang digunakan dalam penelitian ini adalah Rapid Appraissal for Fisheries (RAPFISH). Analisis RAPFISH digunakan untuk mengevaluasi sustainability dari perikanan secara multidisipliner. Metode ini analisis dilakukan terhadap semua dimensi secara bersama sehingga dihasilkan suatu vector skala. Rapfish menggambarkan kondisi yang dianalisis secara cepat dan komprehensif dengan hasil cukup akurat status keberlanjutan sumber daya, dan akhirnya dapat dijadikan bahan untuk menentukan kebijakan yang tepat. Rapfish merupakan sebuah metode MCA (Multi Criteria Analysis), yang dioperasikan dengan teknik ordinasi (menempatkan pada urutan atribut yang terukur) menggunakan Multi-Dimensional Scaling (MDS) (Pitcher \& Preikshot, 2001; Pitcher, 1999; Suresha Adiga, Ananthan, Ramasubramanian \& Divya Kumari, 2015). Pada awalnya metode ini dikembangkan untuk kebijakan pembangunan perikanan berkelanjutan, tetapi kini berkembang untuk bidang-bidang lain termasuk kehutanan, pertanian, peternakan dan pengelolaan lingkungan (Erwina, Kurnia \& Yonvitner, 2016; Muhsoni \& Sofarini, 2016; Tetelepta, Natan, Pattikawa, Ongkers \& Pattiasina, 2019; Warningsih, Hendrik \& Suaseh, 2020; Fikri, Darmono, Tetelepta, Damora \& Muzammil, 2018). 


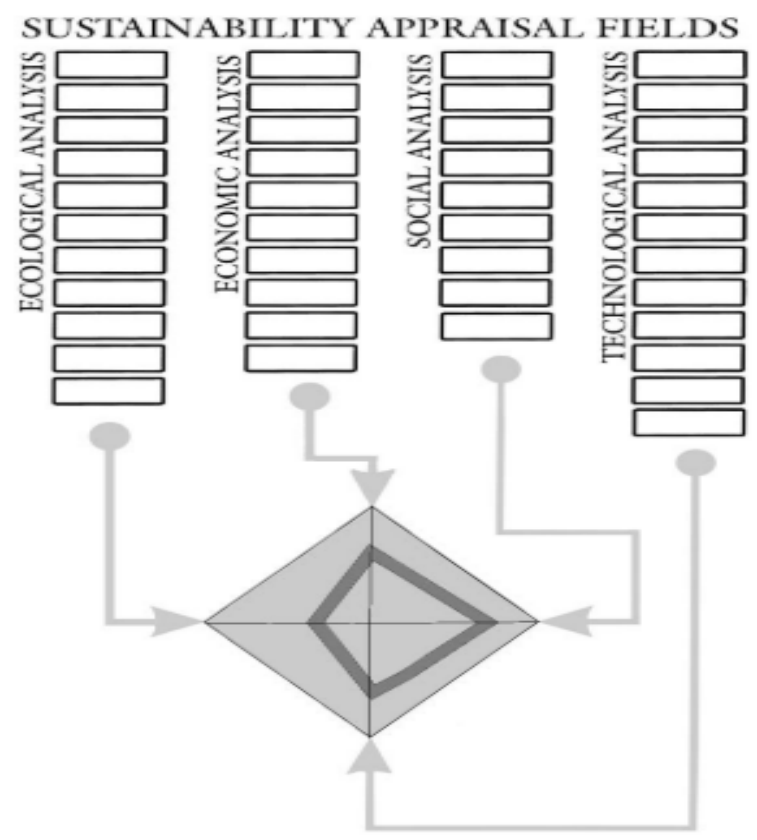

Gambar 1. Analisis Rapfish Dengan Diagram LayangLayang.

Figure 1. Rapfish Analysis With Kite Diagrams.

Sumber:(Pitcher \& Preikshot, 2001; Cissé et al., 2014)/

Source:(Pitcher \& Preikshot, 2001; Cissé et al., 2014)

Penelitian ini dilakukan dalam tujuh tahapan. Pertama adalah penetapan lima dimensi yang akan dianalisis. Kelima dimensi tersebut adalah dimensi ekologi (9 atribut), ekonomi (6 atribut), sosial (5 atribut), sumber daya (5 atribut), dan Hukum dan kelembagaan (8 atribut). Kedua adalah skoring aspek berkelanjutan pada masingmasing dimensi (pada skala 1-5). Ketiga adalah penyajian hasil skoring dalam skala ordinal dengan analisis Multi-Dimensional Scaling (MDS). Keempat adalah penentuan posisi pengelolaan pada ordinal bad dan good Kelima adalah analisis kestabilan atribut dengan Monte Carlo Analysis. Keenam adalah identifikasi atribut sensitif dengan sensitifity analysis (Leverage analysis, identifikasi ini untuk menentukan atribut mana yang sensitif untuk mengubah ordinasi.). Ketujuh adalah penggambaran skala indeks keberlanjutan dalam diagram layang-layang (Gambar 1) (Kavanagh \& Pitcher, 2004).
Pada dimensi ekologi, hasil pengukuran perairan dibandingkan dengan Keputusan Menteri Negara Lingkungan Hidup No. 51 Tahun 2004 (Kementerian Negara Lingkungan Hidup, 2004). Pada dimensi hukum dan kelembagaan, batasannya adalah apakah ada peraturan-peraturan yang mendukung pengembangan pelabuhan kamal sebagai wisata bahari dan kegiatan-kegiatan lembaga pemerintah dan non pemerintah yang secara aktif melakukan kegiatan untuk mendukung Kamal sebagai wisata bahari. Dimensi sumber daya sifatnya berupa fisik dan faktor lingkungan. Dimensi ekonomi merupakan kegiatan-kegiatan ekonomi yang dapat memberikan pendapatan bagi masyarakat Kamal.

Skala keberlanjutan ditunjukkan pada pada Tabel 1. Jumlah responden dalam penelitian ini sebanyak 50 orang, terdiri dari: aparat desa, pedagang makanan, pedagang oleh-oleh, pedangan souvenir, angkutan umum dalam pelabuhan, kuli angkut pelabuhan, petugas pelabuhan, pekerja besi tua kapal bekas, warga di sekitar pelabuhan. Penentuan jumlah responden ini mengikuti panduan yang tertulis dalam Suparyanto (2010), menjelaskan disarankan jumlah responden untuk uji minimal 30 responden. Responden yang dipilih adalah orang yang melakukan aktifitas secara langsung yang berhubungan dengan pelabuhan Kamal. Penentuan responden menggunakan teknik purposive sampling (Sugiyono, 2017; Sudiarta \& Suardana, 2016; Mahfrudin, Yuniarti \& Ruchimat, 2020).

\section{POTENSI PELABUHAN KAMAL}

Hasil identifikasi lapang menunjukkan bahwa potensi wisata di kawasan Pelabuhan Kamal terdapat pada dua dermaga, yaitu Dermaga Barat dan Dermaga Timur, perkampukan di sekitar dermaga, budaya lokal, dan pesisir pantai. Dermaga Timur mempunyai pemandangan yang indah, tempat berkumpul atau tempat kegiatan kuliner, dengan dukungan empat lokasi resto. Posisi Dermaga Timur yang menjorok ke pantai

Tabel 1. Indeks Status Keberlanjutan Pengelolaan.

Table 1. Management Sustainability Status Index.

\begin{tabular}{ccl}
\hline No. & $\begin{array}{c}\text { Nilai Indeks/ } \\
\text { Index Value }\end{array}$ & \multicolumn{1}{c}{$\begin{array}{c}\text { Kategori Keberlanjutan/ } \\
\text { Sustainability Category }\end{array}$} \\
\hline 1 & $0-25$ & Tidak Berkelanjutan/Not sustainable \\
2 & $>25-50$ & Kurang Berkelanjutan/Less sustainable \\
3 & $>50-75$ & Cukup Berkelanjutan/Simply sustainable \\
4 & $>75-100$ & Sangat Berkelanjutan/Very sustainable \\
\hline Sumber: (Purwaningsih \& Santosa, 2015; Erwina et al., 2016)/Source: (Purwaningsih \& Santosa, 2015. Erwina et al., 2016)
\end{tabular}


memiliki panorama utama berupa Jembatan Suramadu. Sementara itu, Dermaga Barat memiliki panorama matahari terbenam, dengan bangunanbangunan yang dapat pula dimanfaatkan untuk sarana penunjang wisata, kegiatan perdagangan. Dermaga Barat juga memungkinkan untuk pengembangan jasa dan terminal. Hal ini dapat dikembangan dengan mememnfaatkan dua bangunan bekas kantor ASDP seluas $1.036 \mathrm{~m}^{2}$ dan $958 \mathrm{~m}^{2}$, bekas pasar oleh-oleh dan souvenir seluas $1.675 \mathrm{~m}^{2}$, kios makan di Dermaga । seuas $344 \mathrm{~m}^{2}$ ), kios makan di Dermaga II seluas $825 \mathrm{~m}^{2}$ ), lapangan Dermaga I seluas 3.442 $\mathrm{m}^{2}$, terminal pelabuhan seluas $5.809 \mathrm{~m}^{2}$; (3) Perkampungan di dekat pelabuhan pun potensial dikembangkan untuk wisata kampong. Kampung kejawan, dengan luas $37.940 \mathrm{~m}^{2}$, posisi kampung disebelah pelabuhan yang menghubungkan Pelabuhan I dan II merupakan kampung yang indah apabila dibenahi. Kemudian, budaya lokal selamatan laut berupa festival bahari Kamal, biasanya diadakan bulan Desember juga merupakan tradisi yag memiliki nilai jual wisata. Sejanjutnya, potensi yang juga perlu dipertimbangnan adalah pesisir pantai, yang dapat dikembangkan untuk lokasi kuliner, terletak di jalur masuk pelabuhan II kearah Batuporon dengan panjang sekitar 750m. Lokasi potensial dapat dilihat pada Gambar 2.

\section{DIMENSI EKOLOGI}

Analsis Rapfish indeks keberlanjutan untuk dimensi ekologi menghasilkan nilai 43,52. (Gambar 3a). Nilai ini masuk dalam kategori 'kurang berkelanjutan', yaitu berada pada kisaran dengan nilai indeks $>25-50$. Dengan nilai stress sebesar 0.1370 dan R2 sebesar 95,2\%, mengacu pada Kavanagh \& Pitcher (2004) hasil tersebut memiliki ketepatan yang tinggi. Analisis dimensi ekologi ini menempatkan atribut-atribut $\mathrm{pH}$, kandungan fosfat dan kecerahan perairan sebagai 3 atribut yang paling berpengaruh pada dimensi tersebut (Gambar 3b).

Pada Gambar 3a dan 3b adalah gambaran lapang tentang atribut-atribut pada dimensi ini. Lokasi di sekitar pemukiman dan pemotongan kapal pada kondisi sedikit berbau, lokasi dok kapal agak bau, lokasi pelabuhan penyebrangan kapal feri sangat bau. Terkait kecerahan perairan, teridentifikasi bahwa semua lokasi memiliki kecerahan < $2 \mathrm{~m}$. Sampah ditemukan di sepanjang pantai, area pemukiman dan pelabuhan. Lapisan minyak banyak terdapat di perairan, terutama di Pelabuhan Timur, area pemotongan kapal dan pemukiman. Untuk keasaman, diperoleh nilai rata-rata $\mathrm{pH}$ perairan antara 6,9-7,7 atau dalam kondisi baik atau cukup baik. Nilai DO perairan berada pada kisaran 4,2-4,5 mg/l atau dalam kondisi cukup/kurang baik. Kandungan fosfat perairan berkisar antara 5,53-5,55 mg/l atau dalam kondisi sangat baik. Kandungan nitrat berada pada kisaran 0,001-0,195 $\mathrm{mg} / \mathrm{l}$ atau dalam kondisi tidak baik. Kandungan timbal di perairan berkisar antara 0,005-0,043 mg/l atau dalam kondisi cukup tinggi. Mengacu pada baku mutu air laut untuk wisata bahari (Kementerian Negera Lingkungan Hidup, 2004; Mutmainah \& Adnan, 2018), nilai-nilai tersebut di atas menunjukkan bahwa bahwa kondisi

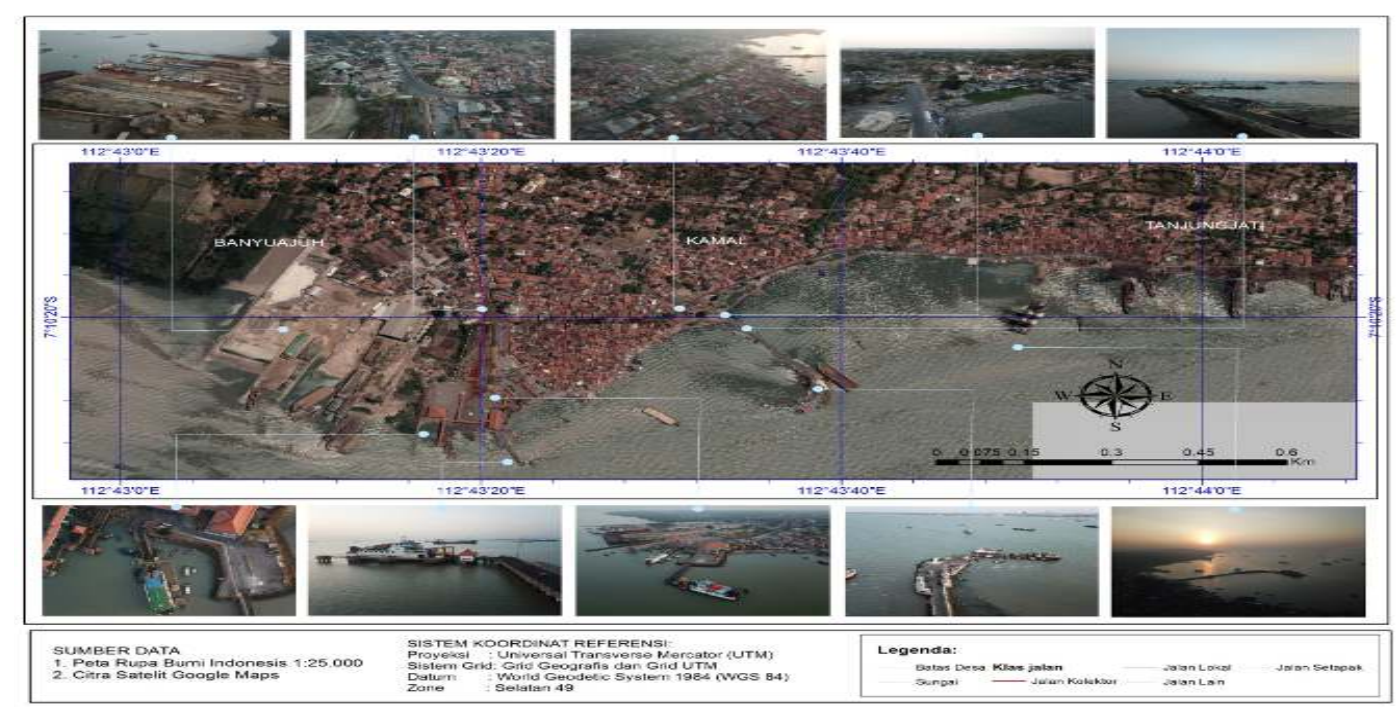

Gambar 2. Potensi Pelabuhan Kamal Pengambilan Gambar Menggunakan Drone. Figure 2. Potential of the Kamal Port Taking Pictures Using Drones.

Sumber: Data lapang (2019)/Source:Field data (2019) 


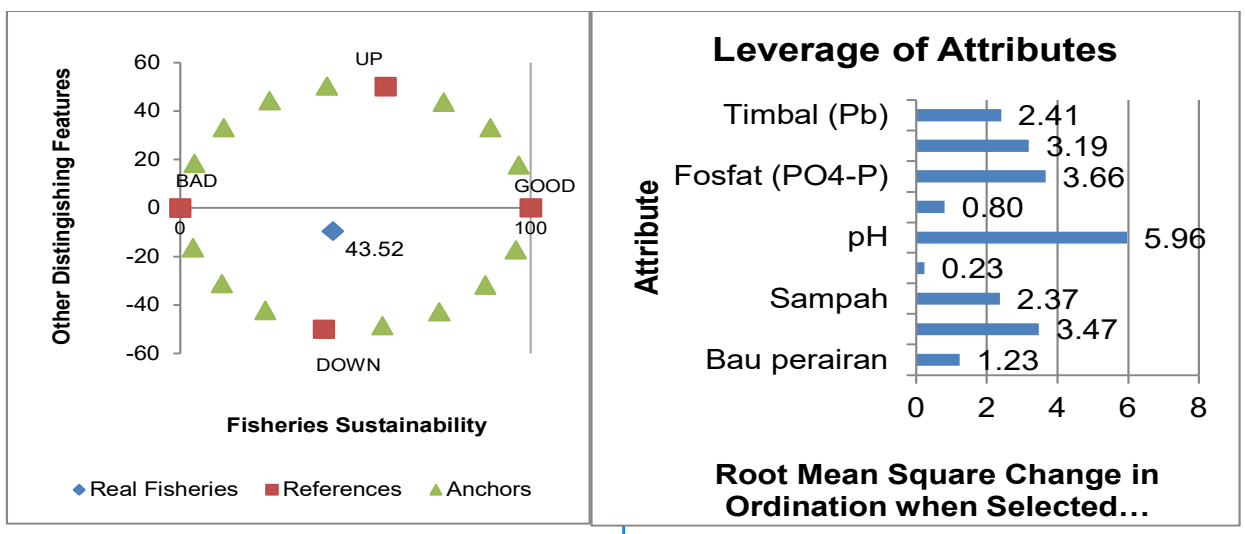

Gambar 3a. Hasil Rap Analysis Dimensi Ekologi; 3b. Faktor Sensitif yang Mempengaruhi Keberlanjutan Ekologi. Figure 3a. Results of Rap analysis of Ecological Dimensions; 3b. Sensitive Factors That Affect Environmental Sustainability.

Sumber: Data lapang (2019)/Source:Field data (2019)

ekologi perairan Pelabuhan Kamal berada dibawah angka-angka baku mutu air laut yang dipersyaratkan untuk wisata bahari. .

\section{DIMENSI SUMBER DAYA}

Analisis Rapfish indeks keberlanjutan dimensi sumber daya menghasilkan nilai 31,84 (Gambar 4a). Nilai ini masuk dalam kategori 'kurang berkelanjutan', yaitu berada pada kisaran dengan nilai indeks $>25-50$. Dengan nilai stress sebesar 0.1457 dan R2 sebesar 92,26\%, mengacu pada Kavanagh \& Pitcher (2004) hasil tersebut memiliki ketepatan yang tinggi. Hasil analisis leverage keberlajutan sumber daya menunjukkan bahwa atribut-atribut paling berpengaruh adalah 'pemukiman penduduk', 'hasil penangkapan ikan', dan 'pembuangan limbah' (Gambar 4b).
Berdasarkan data statistik, jumlah penangkapan di laut di Kecamatan Kamal tahun 2013 adalah sebesar 98,6 ton dan tahun 2016 sebesar 117 ton (Dinas Komunikasi dan Informatika Kabupaten Bangkalan, 2017). Jumlah penangkapan ini hanya $0,4 \%$ dari hasil tangkap di Kabupaten Bangkalan; akan tetapi, hasil dari wawancara dengan nelayan yang melakukan penangkapan di perairan Kamal menunjukkan bahwa penangkapan ikan di sekitar perairan Kamal sudah banyak mengalami penurunan dibandingkan 25 tahun lalu; penurunan tersebut bahkan terjadi lebih dari 50\%. Kondisi tersebut bersifat negatif untuk perikanan tangkap, namun pengamatan di lapangan menunjukkan fakta di mana hampir setiap hari di sekitar pelabuhan Kamal ditemukan masyarakat yang memancing ikan untuk tujuan hobi. Dari sudut pandang pengembangan wisata, hal ini dapat dipandang

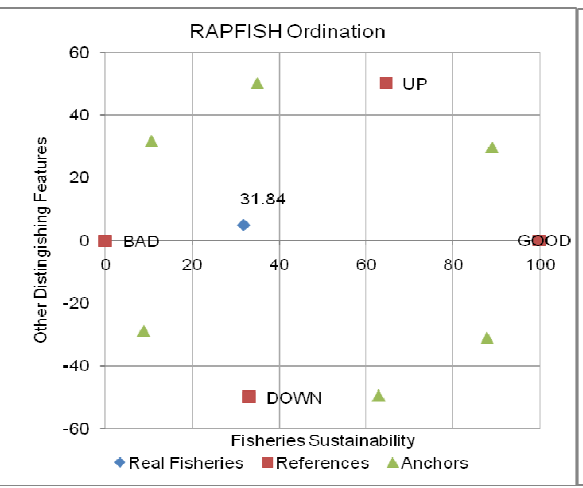

\section{Leverage of Attributes}



Root Mean Square Change in Ordination when Selected...

Gambar 4a. Hasil Rap Analysis Dimensi Sumber Daya; 4b. Faktor Sensitif yang Mempengaruhi Keberlanjutan Potensi Sumber Daya.

Figure 4a. Results of RAP Resource Analysis; 4b. A Sensitive Factor That Affects the Sustainability of Resource Potential.

Sumber: Data lapang (2019)/Source:Field data (2019) 
sebagai potensi untuk perikanan rekreasi (recreational fishing).

Aspek negatif yang ada pada dimensi ini adalah bahwa sejauh ini belum ada penataan yang baik. View di Pelabuhan Timur dan Barat sangat baik untuk wisata kuliner di pesisir pantai, potensi wisata budaya, dan potensi kampung wisata, namun masyarakat membuang limbah ke laut dan membuat MCK di sekitar pantai. Vegetasi atau pohon di sepanjang pelabuhan Kamal masih sangat jarang dan perlu diperrimbun apabila lokasi tersebut akan dijadikan tempat wisata. Sementara itu, permukiman di sepanjang pesisir ditemukan dalam kondisi kurang tertata. Setyaningrum, Budi, \& Masduqi (2017) keberagaman sumber daya alam pesisir seperti ini merupakan aspek positif dalam pengembangan wisata baru.

\section{DIMENSI EKONOMI}

Analisis Rapfish indeks keberlanjutan dimensi ekonomi menghasilkan nilai 35,78 (Gambar 5a). Nilai ini masuk dalam kategori 'kurang berkelanjutan', yaitu pada kisaran nilai indeks >25-50. Dengan nilai stress sebesar 0.1401 dan R2 sebesar 94,7\%, mengacu pada Kavanagh \& Pitcher (2004) hasil tersebut memiliki ketepatan yang tinggi. Hasil analisis leverage untuk dimensi ekonomi menunjukan tiga atribut paling berpengaruh, yaitu 'kerjasama dengan orang luar', 'sumbangan terhadap PDRB' dan 'keberadaan kegiatan bernuansa wisata bahari' Gambar 5b.
Terdapat $59 \%$ masyarakat yang memanfaatkan sumber daya di sekitar Pelabuhan Kamal, antara lain: menjual makanan dan oleh-oleh, menjual cendera mata, menjual buah-buahan lokal, usaha angkutan umum dari pelabuhan, usaha besi tua dari kapal bekas Sementara itu, 41\% masyarakat tidak memanfaatkan sumber daya di sekitar pelabuhan; mereka adalah masyarakat yang tinggal di Kamal namun bekerja di tempat lain, misal Surabaya. Menurunnya kesempatan di Pelabuhan Kamal terjadi sejak diresmikannya jembatan Suramadu, yang menyebabkan penurunan jumlah penumpang dan jumlah kapal yang beroperasi (Andriyani, et al., 2019). Karena itu, potensi yang masih ada masih terabaikan dan perlu dikembangkan sehingga masyarakat bisa memanfaatkan potensi tersebut untuk mencari nafkah. Dampak lain yang terjadi adalah hilangnya pemasukan dari Pelabuhan Kamal dalam bentuk restruibusi jasa penyebrangan, baik untuk kabupaten maupun desa. Hal tersebut terjadi karena setelah keberadaan jembatan Suramadu, ASDP yang merupakan pengelola mengalami kerugian. Pendapatan masyarakat yang membuka usaha menjual makanan dan oleh-oleh, menjual cendera mata, menjual buah-buahan lokal di pelabuhan sebagian besar penghasilannya di bawah UMR Kabupaten Bangkalan tahun 2019 (Rp1.801.406,-). Investasi yang ada sekarang sebagian besar investasi yang mendirikan usaha di sekitar Pelabuhan adalah pendatang (usaha besi tua kapal bekas, dokingkapal). Penyerapan tenaga kerja untuk masyarakat kecil di sekitar pelabuhan rendah (<20\% dari jumlah responden).

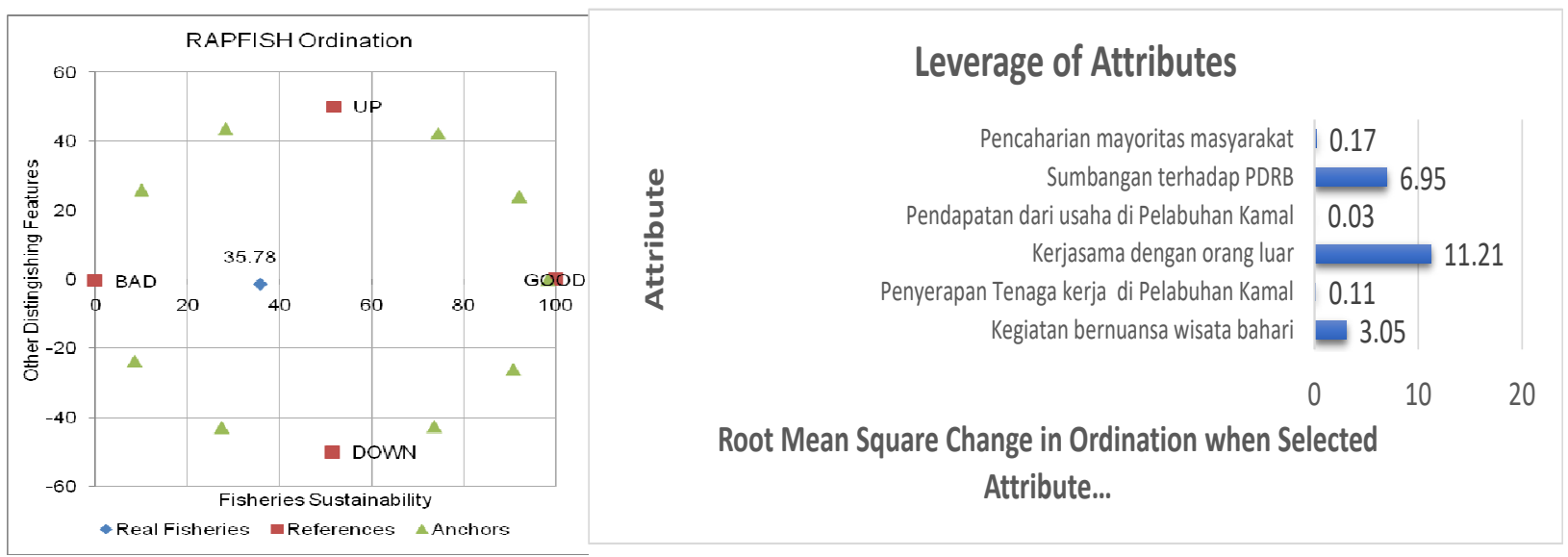

Gambar 5a. Hasil Rap Analysis Dimensi Ekonomi; 5b. Faktor Sensitif yang Mempengaruhi Keberlanjutan Ekonomi.

Figure 5a. Results of RAP Economic Dimension Analysis; 5b. Sensitive Factors That Affect Economic Sustainability.

Sumber: Data lapang (2019)/Source:Field data (2019) 
Hal tersebut dikarenakan minimnya lapangan pekerjaan di Pelabuhan Kamal akibat sepinya penyebrangan. Pengembangan Pelabuhan Kamal untuk wisata bahari merupakan potensi usaha yang belum dikembangkan di Pelabuhan Kamal.

\section{DIMENSI SOSIAL}

Dimensi sosial menunjukkan nilai Rap Analysis sebesar 31,84 (Gambar 6a). Nilai ini masuk dalam kategori 'kurang berkelanjutan', yaitu dalam kisaran nilai indeks >25-50). Maknanya adalah bahwa banyak aspek sosial yang lemah, yang menjadi faktor yang perlu diperbaiki untuk mengembangkan Pelabuhan Kamal. Dengan nilai stress sebesar 0.1433 dan R2 sebesar 94,8\%, mengacu pada Kavanagh \& Pitcher (2004) hasil tersebut memiliki ketepatan yang tinggi. Hasil analisis leverage keberlajutan sosial menunjukkan adanya tiga atribut yang paling berpengaruh yaitu: 'konflik pemanfaatan pelabuhan', 'konflik antar pengguna sumber daya', 'pemahaman pencemaran' (Gambar 6b).

Charles (2001) dan Dyawati, Lidya, Ini \& Pahrozi (2018) membedakan konflik yang muncul terkait pemanfaatan sumber daya perikanan menjadi 4 tipologi: fishery jurisdiction, management mechanism, internal allocation, external allocation. Dalam kajian ini konflik yang dimaksud adalah jenis internal allocation, yaitu konflik antara sesama pengguna sumber daya, misalnya antara nelayan dengan pengusaha. Di Pelabuhan Kamal, tingkat konflik pemanfaatan pelabuhan dan sekitarnya relatif nihil, sehingga lokasi ini potensial untuk pengembangan usaha yang mendukung wisata bahari.
Terkait, pemahaman aspek lingkungan, diperoleh bahwa masyarakat telah memiliki pemahaman bahwa membuang sampah ke pantai berakibat mencemari laut, namun di sepanjang pantai masih banyak ditemukan sampah. Perlu ada peningkatan kesadaran masyarakat, penambahan sarana tempat sampah dan dukungan pemerintah kabupaten agar pengangkutan sampah ke tempat pembuangan akhir bisa lebih terjadwal. Terdapat usaha yang bisa mengakibatkan pencemaran perairan, sehingga perlu dilakukan penanganan limbah agar tidak mencemari perairan. Masyarakat paham bahwa limbah industri atau rumah tangga perlu dilakukan pengolahan sebelum di buang ke perairan, namun sarana dan fasilitas pengolahan belum ada.

Tidak ada konflik antara sesama pengguna sumberdaya, misalnya antara nelayan dengan pengusaha atau antar kelompok masyarakat di sekitar pelabuhan dari hasil kuisioner yang dapat menghambat pengembangan pelabuhan Kamal. Karena itu, masyarakat pun mendukung pengembangan Pelabuhan Kamal, untuk dikembangkan menjadi Wisata Bahari.

\section{DIMENSI HUKUM DAN KELEMBAGAAN}

Dimensi Hukum dan kelembagaan menunjukkan nilai Rap Analysis sebesar 10,33 (Gambar 7a). Nilai ini masuk dalam kategori 'tidak berkelanjutan', yaitu dalam kisaran nilai indeks $\leq 25$. Dengan nilai stress sebesar 0.1497 dan R2 sebesar $94,5 \%$, mengacu pada Kavanagh \& Pitcher (2004) hasil tersebut memiliki ketepatan yang tinggi. Hasil analisis
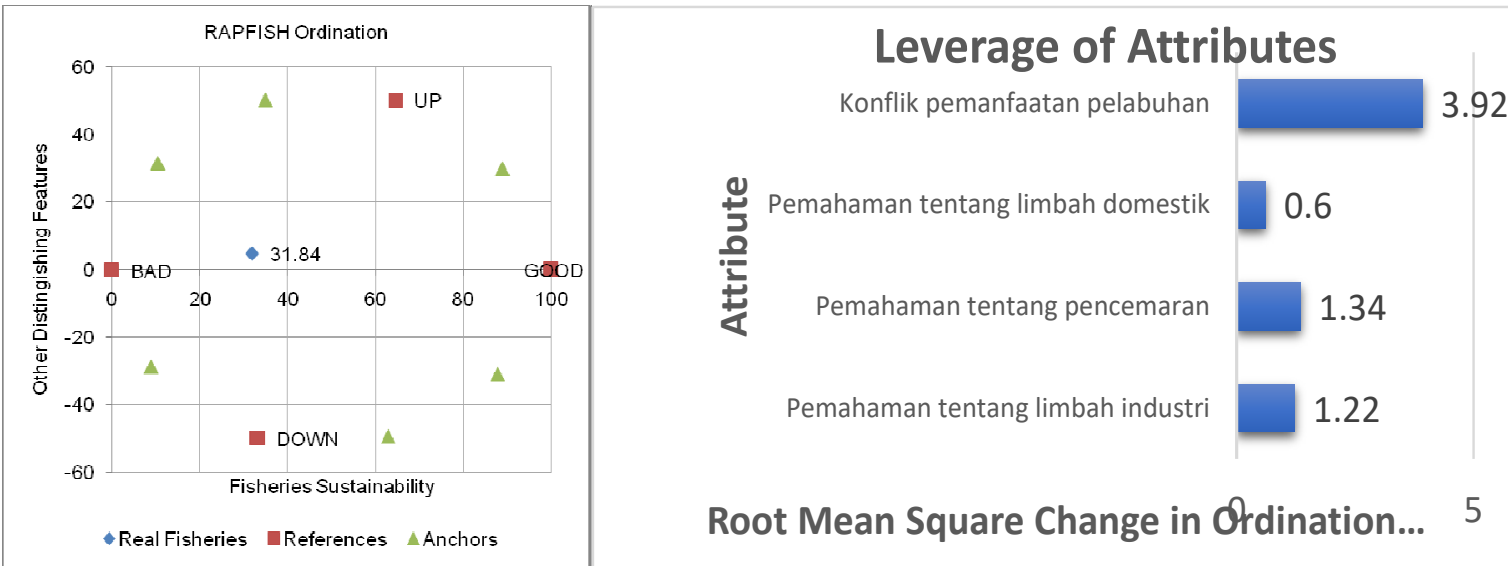

Root Mean Square Change in Ordination... 5

Gambar 6a. Hasil Rap Analysis Dimensi Sosial; 6b. Faktor Sensitif yang Mempengaruhi Keberlanjutan Sosial. Figure 6a. Results of RAP Analysis of The Social Dimension; 6b. Sensitive Factors That Influence Social Sustainability.

Sumber: Data lapang (2019)/Source:Field data (2019) 
leverage dimensi hukum dan kelembagaan menunjukkan adanya tiga atribut paling berpengaruh yaitu 'keterlibatan masyarakat', 'dukungan lembaga pendidikan', dan 'keberadaan kegiatan pemerintah yang terkait' (Gambar 7b).

Belum ada lembaga pemerintah yang khusus mengelola pengembangan pelabuhan. Tidak ada lembaga permodalan yang mendukung usaha masyarakat sekitar pelabuhan baik swasta maupun pemerintah. Kegiatan pemerintah yang khusus mendukung pelabuhan untuk pengembangan sebagai wisata bahari masih sangat terbatas dan belum fokus. Belum ada peraturan baik tingkat kabupaten atau desa berkenaan dengan wisata bahari Kamal. Peran masyarakat dalam mendukung pengembangan Kamal menjadi wisata bahari belum signifikan. Peran lembaga pendidikan juga masih sangat sedikit dalam mendukung Kamal menjadi wisata bahari. Belum ada penyuluhan atau bimbingan dari aparat terkait dengan masalah-masalah yang terjadi di pelabuhan Kamal. Mengacu pada Erwiantono, Susilo, Aditya, Saleha \& Budiayu (2016), hal yang perlu dilakukan dalam kondisi seperti ini adalah revitalisasi peran lembaga lokal dengan meningkatkan kemampuan teknis, manajerial dan sosial ekonominya.

Hasil-hasil analisis Rapfish di atas menunjukkan bahwa indeks keberlanjutan wisata bahari yang direncanakan dikembangkan di Pelabuhan Kamal mempunyai nilai rata-rata 39,37 dan dikategorikan sebagai 'kurang berkelanjutan'. Di antara lima dimensi yang dianalisis, nilai keberlanjutan tertinggi ditunjukkan oleh dimensi sosial, diikuti berturut-turut oleh (indeks 67,53), diikuti berturut-turut oleh dimensi ekologi $(49,42)$, dimensi ekonomi (35,78), dimensi potensi sumber daya $(31,84)$, dan dimensi hukum dan kelembagaan (10,33) (Gambar 8). Hasil ini mengkonfirmasi bahwa pengembangan Pelabuhan Kamal menjadi lokasi wisata bahari memerlukan intervensi pada hampir semua dimensi apabila rencana tersebut akan diteruskan.

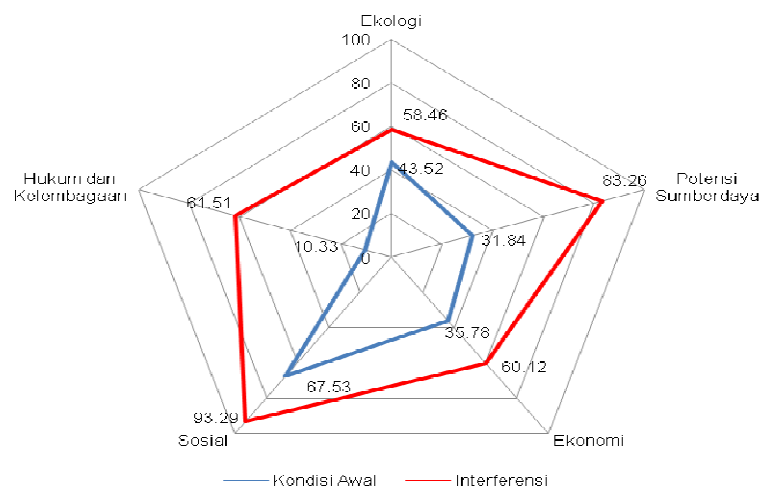

Gambar 8. Diagram Layang Analisis Indeks dan Status Keberlanjutan Hasil Interferensi Untuk Pengembangan Pelabuhan Kamal.

Figure 8. Chart Analysis Index Elevation and Sustainability Status of Interference Results For the Development of the Kamal Port.

Sumber: Data lapang (2019)/Source:Field data (2019)

Nilai rendah pada pembacaan indeks keberlanjutan kelima dimensi tersebut, hasil analisis leverage pada bagian lain memberikan petunjuk tentang atribut-atribut yang perlu


Gambar 7a. Hasil RAP Analisis Dimensi Hukum dan Kelembagaan; 7b. Faktor Sensitif yang Mempengaruhi Keberlanjutan Hukum dan Kelembagaan.

Figure 7a. Results of RAP on the Analysis of the Legal and Institutional Dimensions; 7b. Sensitive Factors That Affect Tthe Sustainability of Law and Institutions.

Sumber: Data lapang (2019)/Source:Field data (2019) 
diprioritaskan pada masing-masing dimensi. Pada dimensi ekologi, atribut-atribut tersebut adalah 'pH', 'kandungan fosfat' dan 'kecerahan' pada perairan yang direncanakan menjadi lokasi wisata. Pada dimensi sumber daya, atributatribut utamanya adalah'penataan pemukiman penduduk', 'hasil penangkapan ikan', dan 'pembuangan limbah'. Pada dimensi ekonomi, atribut-atribut utamanya adalah 'kerjasama dengan orang luar', 'sumbangan terhadap PDRB' dan 'keberadaan kegiatan wisata bahari'. Pada dimensi sosial, atribut-atribut utamanya adalah 'konflik pemanfaatan pelabuhan', 'konflik antar pengguna sumber daya', dan 'pemahaman tentang pencemaran'. Sementara itu, pada dimensi hukum dan kelembagaan, tiga atribut utama yang teridentifikasi adalah 'keterlibatan masyarakat', 'dukungan lembaga pendidikan', dan 'keberadaan kegiatan pemerintah yang terkait'

Pengamatan di lapang menunjukkan bahwa sejumlah atribut dapat ditingkatkan kondisinya melalui satu bentuk intervensi yang sama. Sebagai contoh, aroma tidak sedap dari lingkngan pantai pada dasarnya berasal dari sumber yang sama dengan penyebab rendahnya indikator baku mutu perairan ( $\mathrm{pH}$, kandungan fosfat, kecerahan). Sampah yang menumpuk di sepanjang pantai dan lapisan minyak di perairan merupakan salah satu sumber permasalahan pada atribut-atribut tersebut, dan dapat karenanya penanganannya perlu diprioritaskan untuk menyasar sejumlah atribut tersebut.

Prioritasi serupa dapat dilakukan untuk sumber-sumber permasalahan lain. Seebagai contoh adalah penangan masalah MCK. Apabila kondisi MCK dibenahi, maka sejumlah atribut bernilai rendah dapat tertangani sekaligus. Atribut tersebut misalnya adalah potensi view wisata pantai dan baku mutu air wisata bahari sebagaimana disebutkan di atas.

\section{IMPLIKASI KEBIJAKAN}

Hasil-hasil di atas mengindikasikan paling tidak dua hal, yang membawa implikasi kebijakan. Pertama adalah perlunya memperbaiki kondisi dari sejumlah atribut, yang dapat dilakukan melalui intervensi kebijakan pada penyebab penyebab utama yang membuat rendahnya nilai dari atribut-atribut tersebut. Kedua adalah perlunya dukungan legal yang mendasari pelaksanaan/penerapan...intervensi-intervensi yang dianggap relevan. Dukungan legal tersebut misalnya adalah dalam bentuk Peraturan Daerah (Perda) yang memberikan tugas kepada aktor utama dalam pelaksanaan berbagai intervensi. Pemerintahan lokal, baik tingkat kabupaten maupun perangkat-perangkat di bawahnya, termasuk pemerintah desa perlu dijadikan sebagai aktor utama yang dicakupi dalam Parda tersebut.

Perda tersebut juga harus mencantumkan jenis-jenis intervensi yang dianggap strategis berdasarkan pada hasil penelitian ini. Intervensiintervensi strategis tersebut tentu saja tidak terlepas dari kendala-kendala yang dihadapi oleh pemerintah daerah, baik dari sisi teknis, sosial maupun keuangan. Untuk itu penyertaan pihakpihak lain yang terkait menjadi sangat penting dalam hal ini. Keterlibatan masyarakat, lembagalembaga pendidikan, dan lembaga swadaya masyarakat, sebagaimana telah dibahas dalam penelitian ini, adalah beberapa contohnya.

\section{UCAPAN TERIMA KASIH}

Terima kasih kepada Lembaga Penelitian dan Pengabdian Masyarakat Universitas Trunojoyo Madura yang telah membiayai penelitian ini.

\section{PERNYATAAN KONTRIBUSI PENULIS}

Berikut adalah deskripsi kontribusi masing-masing masing-masing penulis terhadap penyelesaian makalah ini: Firman Farid Muhsoni (Kontributor Utama), Muhammad Zainuri (Kontributor Anggota), Indah Wahyuni Abida (Kontributor Anggota).

\section{DAFTAR PUSTAKA}

Adiga, S., Ananthan, P. S., Ramasubramanian, V., \& Divya Kumari, H. V. (2015). Validating RAPFISH sustainability indicators: Focus on multi-disciplinary aspects of Indian marine fisheries. Marine Policy, 60, 202-207. DOI: https://doi.org/10.1016/j.marpol.2015.06.032

Akbarwati, E., \& Ariastita, P. G. (2013). Revitalisasi kawasan Pelabuhan Kamal di Madura. Jurnal Teknik POMITS, 2(2), C104-C108. Retrieved from: http://ejurnal.its.ac.id/index.php/ teknik/article/view/4324

Andriyani, K., Muna, Z., \& Nofeti, W. (2019). KSB (Kamal Sunset Beach): Upaya revitalisasi pelabuhan kamal sebagai pendorong perekonomian. Retrieved from: https://Kikiandriyaniblog. Wordpress.Com/Karya-TulisIImiah/Essay/ 
Bisri, M. (2019). Bangkalan ingin hidupkan Pelabuhan Kamal sebagai wisata bahari. Retrieved from: https://nasional.tempo.co/read/862022/ bangkalan-ingin-hidupkan-pelabuhan-kamal-sebagai-wisata-bahari/full\&view=ok

Charles, A. T. (2001). Fishery conflicts and the co-mangement approach. In J. P. Tony (Ed.), Sustainable Fishery Systems (pp. 250-276). CA: Wiley. DOI: https://doi. org/10.1002/9780470698785.ch13

Cissé, A. A., Blanchard, F., \& Guyader, O. (2014). Sustainability of tropical small-scale fisheries: Integrated assessment in French Guiana. Marine Policy, 44, 397-405. DOI: https://doi.org/10.1016/j. marpol.2013.10.003

Dinas Komunikasi dan Informatika Kabupaten Bangkalan. (2017). Statistik Daerah Bangkalan. Retrieved from: http://www.bangkalankab.go.id/ v5/pages/info.php?id=7

Dyawati, Y., Lidya, E., Ini, Y., \& Pahrozi, R. (2018). Konflik sosial ekonomi masyarakat pesisir di Desa Sungsang Kecamatan Banyuasin II Kabupaten Banyuasin Sumatera Selatan. Jurnal Sosiologi Reflektif, 12(2), 251-265. DOI: https:// doi.org/10.14421/jsr.v12i2.1329

Erwiantono, Susilo, H., Aditya, A., Saleha, Q., \& Budiayu, A. (2016). Kebijakan nilai manfaat ekonomi dan pengelolaan ekowisata berkelanjutan di kawasan Labuan Cermin-Kabupaten Berau, Kalimantan Timur. Jurnal Kebijakan Sosial Ekonomi Kelautan Dan Perikanan, 6(1). DOI: https://doi.org/http://dx.doi.org/10.15578/jksekp. v6i1.1611

Erwina, Y., Kurnia, R., \& Yonvitner, Y. (2016). Status keberlanjutan sumber daya perikanan di perairan Bengkulu. Jurnal Sosial Ekonomi Kelautan Dan Perikanan, 10(1). DOI: https://doi.org/10.15578/ jsekp.v10i1.1245

Fikri, I. A., Darmono, O. P., Tetelepta, J. M. S., Damora, A., \& Muzammil, W. (2018). Risk potency analysis and sustainability status of mud crab scylla sp. of Sorbay Bay, Southeast Maluku district, Indonesia. IOP Conference Series: Earth and Environmental Science, 216(1). DOI: https://doi.org/10.1088/1755-1315/216/1/012038

Hartono, T. T., Kodiran, T., Iqbal, M. A., \& Koeshendrajana, S. (2005). Pengembangan teknik rapid appraisal for fisheries (RAPFISH) untuk penentuan indikator kinerja perikanan tangkap berkelanjutan di Indonesia. Buletin Ekonomi Perikanan, 6(1), 65-76. Retrieved from: http://journal. ipb.ac.id/index.php/bulekokan/article/ download/2547/1537

Jannah, A. (2016). Pelabuhan Kamal Tahun 1996-2009. AVATARA, 4(2), 493-507. Retrieved from: https:// jurnalmahasiswa.unesa.ac.id/index.php/avatara/ article/view/14919
Kavanagh, P., \& Pitcher, T. J. (2004). Implementing microsoft excel software for rapfish: a technique for the rapid appraisal of fisheries status. In Fisheries Centre Research Reports (Vol. 12, Issue 2). Retrieved from: https:// open.library.ubc.ca/media/download/ pdf/52383/1.0074801/1

Kementerian Negera Lingkungan Hidup. (2004). Keputusan Menteri Negara Lingkungan Hidup Nomor 51 Tahun 2004 Tentang Baku Mutu Air Laut. Jakarta

Mahfrudin, Z. R., Yuniarti, T., \& Ruchimat, T. (2020). Kajian potensi sumber daya perikanan di Kecamatan Sanden Kabupaten Bantul Provinsi Daerah Istimewa Yogyakarta. Marlin, 1(1). DOI: https://doi.org/http://dx.doi.org/10.15578/marlin. V1.11.2020.47-56

Mira, M. (2014). Indikator kebijakan usaha pembangunan wisata masal di pulau-pulau kecil. Jurnal Kebijakan Sosial Ekonomi Kelautan Dan Perikanan, 4(1). DOI. https://doi.org/10.15578/ jksekp.v4i1.224

Mira. (2015). Atribut Penentu Keberhasilan Program Kapal Bantuan dalam Peningkatkan Kesejahteraan Nelayan. Jurnal PKS, 14(1), 30-43.

Muhsoni, F. F., \& Efendy, M. (2017). Coral reefs eco tourism sustainability management In the Gili Labak Island using rapfish method. Jurnal Kelautan, 10(2). DOI: https://doi.org/10.21107/ jk.v10i2.3235

Muhsoni, F. F., \& Sofarini, D. (2016). Manajemen sumber daya perikanan tangkap di Kabupaten Sampang dengan menggunakan metode rapfish. Seminar Nasional Pengelolaan Sumber daya Perikanan Pelagis Di Indonesia, 51-58. Retrieved from: https://docplayer.info/52635410-Prosiding-seminar-nasional.html

Muhsoni, F. F., Zainuri, M., Rhomadhon, W., \& Afandi, J. T. (2019). Penentuan arahan pemanfaatan wilayah pesisir pelabuhan kamal pasca jembatan Suramadu menggunakan metode analytic hierarchy process. Seminar Nasional Tantangan Dan Peluang Pengelolaan Perikanan Kelautan Berkelanjutan Menyongsong Sustainable Development Goals, 75-80. Retrieved from: http://prosiding-semnas.fpik.ub.ac.id/index.php/ prosemfpik/article/download/15/12

Mutmainah, H., \& Adnan, I. (2018). Status kualitas perairan kawasan terpadu Pelabuhan Perikanan Samudera Bungus menggunakan metode indeks golongan air. Jurnal Teknologi Lingkungan, 19(1), 107. DOI: https://doi.org/10.29122/jtl.v19i1.2030

Pitcher, T. J., \& Preikshot, D. (2001). RAPFISH: A rapid appraisal technique to evaluate the sustainability status of fisheries. Fisheries Research, 49(3), 255-270. DOI: https://doi.org/10.1016/S01657836(00)00205-8 
Pitcher, Tony J. (1999). Rapfish, a rapid appraisal technique for fisheries, and its application to the code of conduct for responsible fisheries. FAO Fisheries Cicular, 947, 52. Retrieved from: http:// www.fao.org/DOCREP/005/X4175E/X4175E00. HTM

Purwaningsih, R., \& Santosa, H. (2015). Pengembangan metode penilaian keberlanjutan (sustainability assessment) klaster industri perikanan. Prosiding SNST Ke-6, 41-46. Retrieved from: https://publikasiilmiah.unwahas.ac.id/index.php/ PROSIDING_SNST_FT/article/view/1110

Salman, G. (2018). Nasib perusahaan kapal penyeberangan, merugi setelah suramadu beroperasi.Regional.Kompas. Com. Retrieved from: https://regional.kompas. com read/2018/10/24/07022451/nasib-perus haan-kapal-penyeberangan-merugi-setelah-su amadu-beroperasi

Setyaningrum, A., Budi, H., \& Masduqi, E. (2017). Strategi pengembangan pariwisata berbasis sumber daya alam pesisir dan laut di pantai Depok Daerah Istimewa Yogyakarta. Jurnal Kebijakan Sosial Ekonomi Kelautan Dan Perikanan, 7(2). DOI: https://doi.org/http://dx.doi.org/10.15578/jksekp. v7i2.3953

Sudiarta, I. N., \& Suardana, I. W. (2016). Dampak pariwisata terhadap kemiskinan di kawasan pariwisata di Bali. Jurnal Kajian Bali, 6(2), 209-228. Retrieved from: https://ojs.unud.ac.id/ index.php/kajianbali/article/view/24361/15804

Sugiyono. (2017). Statistik untuk penelitian. Bandung, ID: CV Alfabeta.

Suparyanto. (2010). Uji validitas kuisioner penelitian. Retrieved from: http://dr-suparyanto.blogspot. com/2010/12/uji-validitas-kuesioner-penelitian. html

Tetelepta, J. M. S., Natan, Y., Pattikawa, J. A., Ongkers, O. T. S., \& Pattiasina, B. J. (2019). Fishery of mud crab Scylla serrata of Kotania Bay, Western Seram District: Potency, stock status and sustainable management. IOP Conference Series: Earth and Environmental Science, 339(1). DOI: https://doi. org/10.1088/1755-1315/339/1/012002

Warningsih, T., Hendrik, H., \& Suaseh, Y. (2020). The status of sustainability of anchovy resources in the Labuhanbatu territorial waters, North Sumatra Province. IOP Conference Series: Earth and Environmental Science, 430(1). DOI: https://doi. org/10.1088/1755-1315/430/1/012021

Widjajanto, R., Kumalawati, N., \& Zefri. (2017). Faktor penyebab sulit berkembangnya kawasan Pelabuhan Kamal. Eco-Entrepreneur, 3(225-234). Retrieved from: https://journal.trunojoyo.ac.id/ eco-entrepreneur/article/view/3034 